\title{
Q-Fever Studies on the Dairy Cattle of Puerto Rico
}

\author{
Gilberto Rosado-Carbó, Carlos N. Berrocal, and José D. Rivera-Anaya ${ }^{1}$
}

\section{INTRODUCTION}

Q-fever in man is an acute disease resembling influenza. It was first described as a human disease in 1937 in Queensland, Australia. The etiological agent of Q-fever, originally described as Rickettsiae burnetii, $(2,4,5),{ }^{2}$ is listed in Bergey's Manual of Determinative Bacteriology as Coxiella burnetii (1).

\section{OBJECTIVE}

The Q-fever organism was recovered in the United States in 1938 ( 8 ) and the disease is widespread in that country at present (9).

The disease is transmitted among cattle by ticks ( 7$)$, and herd-to-herd transmission has been demonstrated (12). Apparently, Q-fever produces a mild or subclinical illness in domestic animals. The organism, claimed to be very resistant to pasteurization temperatures (6), has been demonstrated in the milk and the placentae of cows $(8,10)$.

Since cattle are being constantly imported into Puerto Rico from the United States, the conduct of a survey to determine whether Q-fever antibodies were present in our herds seemed justified. The presence of Q-fever antibodies in cattle should make the sanitary officials of Puerto Rico aware of the possibility that this disease might have been the cause in cases of suspected human influenza for which no definite etiological agent could be identified.

\section{PROCEDURE}

The survey was effected from 1962 to 1963 . At the start, there were 626 first-class dairies on the Island, but the number has increased since.

The samples for the detection of Q-fever antibodies were taken from the bulk tanks on the farms, or received from the pasteurizing plants after they had been used for bacteriological examinations. Samples from 561 firstclass dairies were tested.

1 Associate Veterinarian, Assistant Bacteriologist, and Veterinarian, respectively, Agricultural Experiment Station, University of Puerto Rico, Río Piedras, P.R. The authors want to express their appreciation and thanks to Dr. Lauri Luoto, of Rocky Mountain Laboratory, and to the Cyanamid Borinquen Corp. for providing the antigen used in these studies. Acknowledgment is also made to Dr. Charles E. Reed, Ohio State University, for his cooperation and advice, and finally, but not the least, to the milk-pasteurizing plants of Puerto Rico for their gracious and spontaneous help in collecting many of the samples tested.

2 Italic numbers in parentheses refer to Literature Cited, p. 223. 
The milk samples were transported and kept under refrigeration until such time, on the same or the following day, as the agglutination test could be performed.

The capillary-tube agglutination technique developed by Luoto and Mason in 1955 (11) was used. This test, highly specific and sensitive, is used for testing on a herd basis. The antigen consists of a suspension of Coxiella burnetii stained with hematoxylin.

Aliquot parts of antigen and milk were layered by capillarity in a capillary tube by first immersing the tip of the tube into the antigen so that a column of approximately 1 inch of antigen is drawn up into the tube. Milk was similarly drawn into the tube. The tube was inverted, so that the milk layer was uppermost, and imbedded in a vertical position in clay or wax. Results were observed after the tubes are held at $37^{\circ} \mathrm{C}$. for 2 , or at room temperature for 4 , hours. Blue-black macroscopic agglomerates distributed throughout the column, readily visible, indicated a positive reaction. Absence of these agglomerates indicated a negative reaction.

\section{RESULTS}

Out of the 561 samples examined, 278 were positive for Coxiella burnetti antibodies (49.55 percent).

The communities from which positive samples were observed are indicated in table 1 and figure 1, showing the number of dairy herds by township, number of herds sampled, and results obtained. It is noteworthy that over 50 percent of the herds in the two townships having the largest number of dairy herds were positive to the Q-fever agglutination test: Hatillo had 56 out of 98 herds, and Arecibo had 29 out of 48 herds.

\section{DISCUSSION}

The results obtained indicate that the antibodies of Coxiella burnetii, the etiological agent of Q-fever, are widely spread in the dairy herds throughout Puerto Rico. These findings, of interest to the Public Health officials of the Island, might influence their outlook on cases of human influenza of unknown etiology.

It is interesting to note that, at the time this survey was being conducted at the dairy herds of Arecibo, many cases of human influenza were being diagnosed at the City Hospital. Unfortunately, although antigen was provided, no serological tests on human sera were performed there.

\section{SUMMARY}

The presence of Q-fever antibodies was determined in 278 of the 561 milk samples from an equal number of Puerto Rican dairy herds tested by the capillary-tube agglutination technique. The incidence of positive agglutinations was found to be 49.55 percent. 
TABLE 1.-Results of agglutination tests against Q-fever observed in 561 dairy herds, Puerto Rico, 1968-68

\begin{tabular}{|c|c|c|c|c|c|}
\hline \multirow{2}{*}{ Township } & \multirow{2}{*}{ Herds in area } & \multirow{2}{*}{ Herds sampled } & \multicolumn{2}{|c|}{ Results } & \multirow{2}{*}{ Positive } \\
\hline & & & Positive & Negative & \\
\hline $\begin{array}{l}\text { Hatillo } \\
\text { Arecibo } \\
\text { Caguas } \\
\text { Carolina } \\
\text { Manati } \\
\text { Cabo Rojo } \\
\text { Loíza (Canóvanas) } \\
\text { Juncos } \\
\text { Coamo } \\
\text { Luquillo } \\
\text { Naguabo } \\
\text { Dorado } \\
\text { Gurabo } \\
\text { Morovis } \\
\text { Toa Baja } \\
\text { Lajas } \\
\text { Ponce } \\
\text { Toa Alta } \\
\text { Corozal } \\
\text { Vega Baja } \\
\text { Camuy } \\
\text { Juana Diaz } \\
\text { Mayagüez } \\
\text { Bayamón } \\
\text { Rí Grande } \\
\text { Guaynabo } \\
\text { Aguas Buenas } \\
\text { Humacao } \\
\text { Quebradillas } \\
\text { Salinas } \\
\text { Vega Alta } \\
\text { Guayanilla } \\
\text { Las Piedras } \\
\text { Aibonito } \\
\text { Barceloneta } \\
\text { Cidra } \\
\text { Fajardo } \\
\text { Penuuelas } \\
\text { Rio Piedras } \\
\text { Sabana Grande } \\
\text { Trujillo Alto } \\
\text { Yabucoa } \\
\text { Aguadilla } \\
\text { Ciales } \\
\text { Isabela } \\
\text { San Germán } \\
\text { San Lorenzo } \\
\text { Yauco } \\
\text { Aguada } \\
\text { Anasco } \\
\text { Barranquitas } \\
\text { Comerío } \\
\text { Guánica } \\
\text { and }\end{array}$ & $\begin{array}{r}\text { Number } \\
111 \\
54 \\
33 \\
28 \\
27 \\
32 \\
17 \\
19 \\
27 \\
15 \\
15 \\
14 \\
14 \\
13 \\
17 \\
14 \\
17 \\
17 \\
14 \\
9 \\
9 \\
10 \\
12 \\
11 \\
8 \\
8 \\
5 \\
5 \\
5 \\
7 \\
6 \\
4 \\
5 \\
3 \\
4 \\
4 \\
3 \\
3 \\
3 \\
7 \\
6 \\
3 \\
2 \\
2 \\
4 \\
2 \\
2 \\
3 \\
1 \\
1 \\
1 \\
1 \\
3 \\
\end{array}$ & $\begin{aligned} \text { Number } \\
\mathbf{9 8} \\
48 \\
32 \\
26 \\
24 \\
21 \\
17 \\
19 \\
18 \\
15 \\
15 \\
14 \\
14 \\
13 \\
13 \\
12 \\
11 \\
11 \\
10 \\
9 \\
8 \\
8 \\
8 \\
7 \\
7 \\
6 \\
5 \\
5 \\
5 \\
5 \\
5 \\
4 \\
4 \\
3 \\
3 \\
3 \\
3 \\
3 \\
3 \\
3 \\
3 \\
3 \\
2 \\
2 \\
2 \\
2 \\
2 \\
2 \\
1 \\
1 \\
1 \\
1 \\
1 \\
\end{aligned}$ & $\begin{array}{c}\text { Number } \\
56 \\
29 \\
15 \\
14 \\
19 \\
2 \\
10 \\
7 \\
3 \\
7 \\
4 \\
11 \\
5 \\
5 \\
8 \\
1 \\
6 \\
7 \\
9 \\
4 \\
4 \\
2 \\
5 \\
5 \\
4 \\
4 \\
1 \\
3 \\
5 \\
2 \\
3 \\
3 \\
1 \\
1 \\
2 \\
2 \\
2 \\
2 \\
1 \\
2 \\
-1 \\
1 \\
1 \\
\end{array}$ & $\begin{array}{r}\text { Number } \\
42 \\
19 \\
17 \\
12 \\
5 \\
19 \\
7 \\
12 \\
15 \\
8 \\
11 \\
3 \\
9 \\
8 \\
5 \\
12 \\
10 \\
5 \\
3 \\
4 \\
4 \\
4 \\
8 \\
5 \\
2 \\
1 \\
1 \\
1 \\
4 \\
2 \\
4 \\
2 \\
2 \\
2 \\
2 \\
2 \\
3 \\
1 \\
1 \\
1 \\
3 \\
2 \\
2 \\
1 \\
2 \\
1 \\
1 \\
1 \\
1\end{array}$ & $\begin{array}{r}\text { Percent } \\
57.1 \\
60.4 \\
46.8 \\
53.8 \\
79.1 \\
9.5 \\
58.8 \\
36.8 \\
16.6 \\
46.6 \\
26.6 \\
78.5 \\
35.7 \\
38.4 \\
61.5 \\
\overline{9.0} \\
54.5 \\
70.0 \\
100.0 \\
50.0 \\
50.0 \\
\overline{28.5} \\
71.4 \\
83.3 \\
80.0 \\
80.0 \\
20.0 \\
60.0 \\
100.0 \\
\overline{50.0} \\
100.0 \\
100.0 \\
33.3 \\
33.3 \\
\overline{66.6} \\
66.6 \\
66.6 \\
\overline{-} \\
100.0 \\
50.0 \\
100.0 \\
\overline{-} \\
\overline{1} \\
100.0 \\
100.0 \\
-\end{array}$ \\
\hline Total & 660 & 561 & 278 & 283 & 49.65 \\
\hline
\end{tabular}




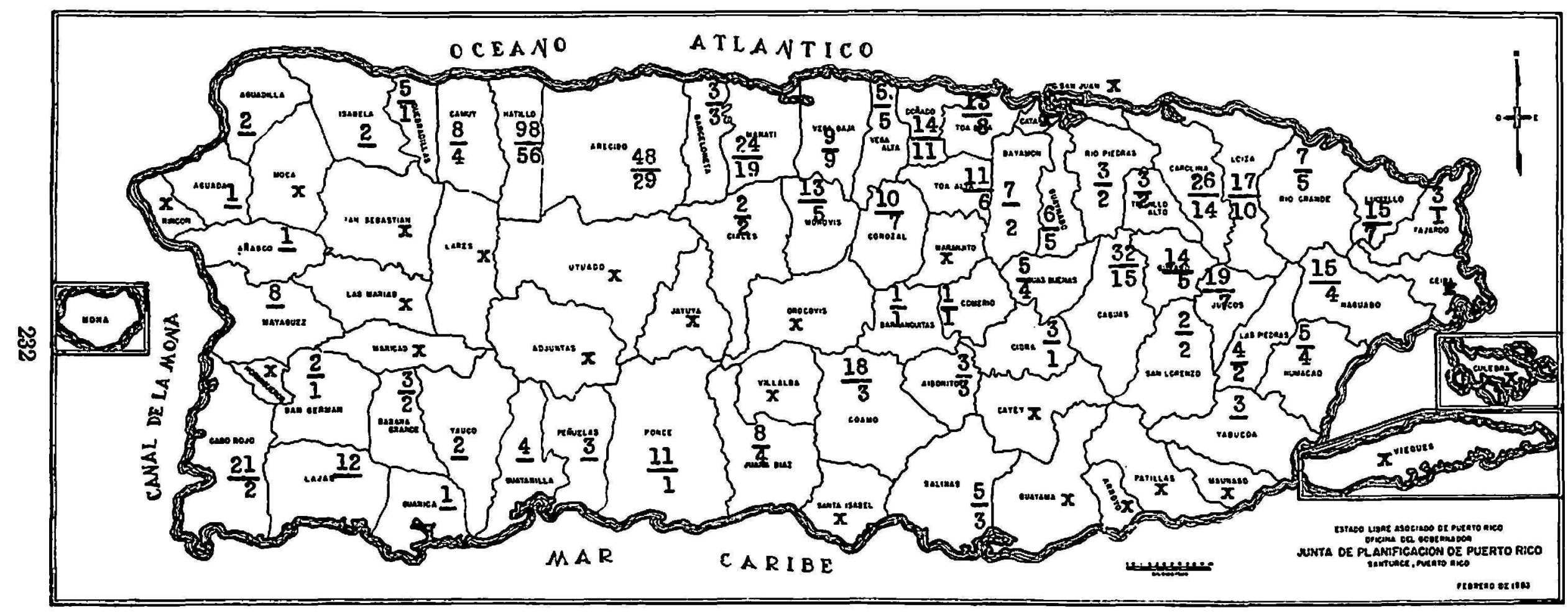

Frg. 1.-Distribution by township of positive agglutination tests against $Q$-fever antigen in 561 dairy herds, Puerto Rico, 1962-63. $x$ : No samples taken in these municipalities. Numerator: Number of herd samples taken. Denominator: Number of positive samples. 
Over 50 percent of the dairies of Hatillo and Arecibo, the two with the largest numbers of dairy herds in Puerto Rico, showed positive agglutinations.

\section{RESUMEN}

Se determinó la presencia de anticuerpos contra la fiebre $Q$ en 278 de las 561 muestras de leche tomadas en un número igual de vaquerías y probadas por el método de aglutinación en tubo capilar. La incidencia de aglutinación positiva fue de 49.55 por ciento.

Se observaron resultados de aglutinación positiva en más del 50 por ciento de las vaquerías de Hatillo y Arecibo, los dos municipios en donde hay el mayor número de vaquerías en Puerto Rico.

\section{LITERATURE CITED}

1. Bergey's Manual of Determinative Bacteriology, 7th ed., Williams \& Wilkins Co., Baltimore, Md., 1957.

2. Burnet, F. M., and Freeman, M., Experimental studies on the virus of " $Q$ " fever, Med.J. Austral. 2: 299-315, 1937.

3. Davis, G. E., and Cox, H. R., A filter-passing infectious agent isolated from ticks, I, Isolation from Dermacontor audersoni, reactions in animals and filtration experiments, Pub. Health Rpts. (US) 58: 2259-67, 1938.

4. Derrick, E. H., "Q" fever, a new fever entity: Clinical features, diagnosis and laboratory investigation, Med. J. Austral. 2: 281-9, 1937.

5. - , Rickettsia burneti, the cause of " $Q$ " fever, Med. J. Austral. 26: 1-14, 1939.

6. Enright, J. B., Sadler, W. W., and Thomas, R. C., Pasteurization of milk containing organisms of "Q" fever, Amer. J. Pub. Health 47: 605-700, 1957.

7. Hagan, W. A., and Bruner, D. W., The Infectious Diseases of Domestic Animals, 4th ed., Comstock Pub. Assocs., Ithaca, N.Y., 1961.

8. Huebner, R. J., Jellison, W. L., Beck, M. D., Parker, R. R., and Shepard, C. C., " $Q$ " fever studies in Southern California, I, Recovery of Rickettsia burneti from raw milk, Pub. Health Rpts. (US), 6s: 214-21, 1948.

9. Luoto, L., Report on the nationwide occurrence of " $Q$ " fever infections in cattle, Pub. Health Rpts. (US), 75: 135-40, 1960.

10. Luoto, L., and Huebner, R. J., "Q" fever studies in Southern California, IX, Isolation of " $Q$ " fever organisms from parturient placentas of naturally infected dairy cows, Pub. Health Rpts. (US), 65: 541-4, 1950.

11. Luoto, L., and Mason, D. M., An agglutination test for bovine " $Q$ " fever performed on milk samples, J. Immunol. 74: 222-7, 1955.

12. Reed, C. E., and Wentworth, B., Q fever studies in Ohio, J. Amer. Vet. Med. Assoc. 180: 458-61, 1957. 